\title{
The process of collecting data for the Acute Myocardial Infarction / Acute Coronary Syndrome Register for the City of Zagreb
}

Inge Heim*

Institute for Cardiovascular Prevention and Rehabilitation, Zagreb, Croatia

Introduction: The Acute Myocardial Infarction Register for the City of Zagreb was established in 1979 in the Institute for Cardiovascular Prevention and Rehabilitation as a population-based register including all cases among Zagreb residents. It contained mostly epidemiological data. As time passed and diagnostic procedures and therapy in cardiology advanced, cardiologists were interested to get more clinical information. In 2003 we established the Acute Coronary Syndrome Register for the City of Zagreb containing a series of clinical data. All age groups are covered. Sources of information are: mortality data and hospital discharge of consecutive patients admitted to all Zagreb hospitals with Acute Cardiology Units. Main inclusion criteria:

- suspected or confirmed acute coronary syndrome (ACS)

- those who died outside hospital with ACS as the main cause of death (confirmed or not confirmed by autopsy).

- sudden cardiac death (in- and out-of-hospital)

Methods: Physicians regularly visit all Zagreb hospitals which have Acute Cardiology Units. In the hospital admission list they look for Zagreb residents who were discharged with a diagnosis of ACS. Data collection method is cold pursuit.
They fill in a questionnaire with the following data: history data (risk factors, previous percutaneous coronary interventions or coronary artery bypass graft surgery), exact date and time of the onset of symptoms, date and time of admission, time of entering coronary care unit, 12-lead ECG on admission, markers of necrosis (CK-MB, troponin), $\mathrm{PCl}$ or PTCA, working diagnosis from the emergency clinic, diagnostic procedures during hospitalization, laboratory findings (TC, HDL, LDL, triglycerides), therapy in the first 24 hours, complications, final diagnosis, groups of drugs taken in the last 3 months prior to arrival at the hospital and medications recommended at discharge, date and place of death (hospital death occurring within 28 days) and whether autopsy was performed. In fatal cases, autopsy report is checked and if it is proven that the cause of death is not an ACS, the patient is not entered in the Register.

Results: The comparison between in-hospital and out-ofhospital death from ACS by gender shows great differences. Out-of-hospital death in men is much higher than in-hospital death and the both show a declining trend seen from 2007 to 2011 (Figure 1). In women we see the opposite (Figure 2). In-hospital death is much higher than out-of-hospital

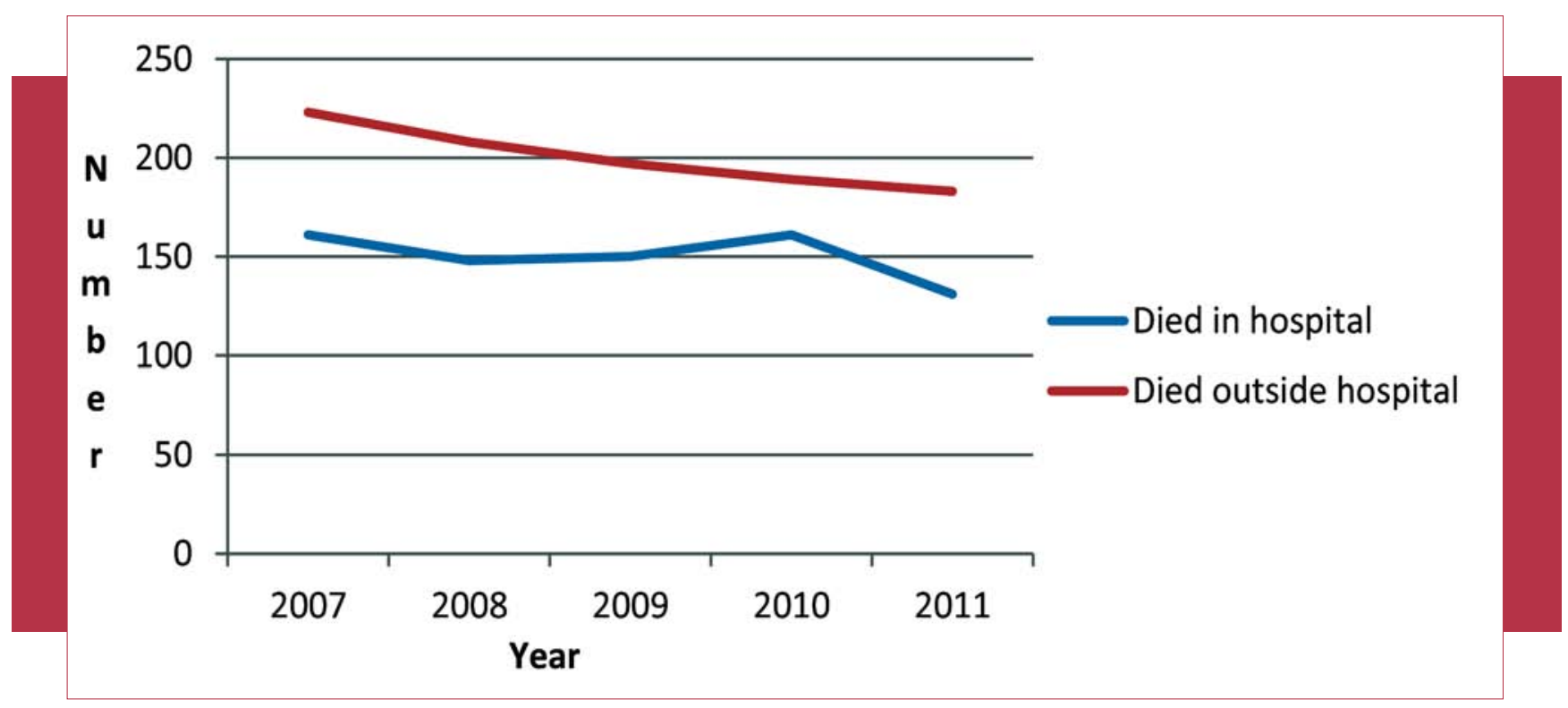

Source: Croatian Bureau of Statistics.

Figure 1. Comparison of in- and out-of-hospital death from acute coronary syndrome among men Zagreb residents (2007-2011). 


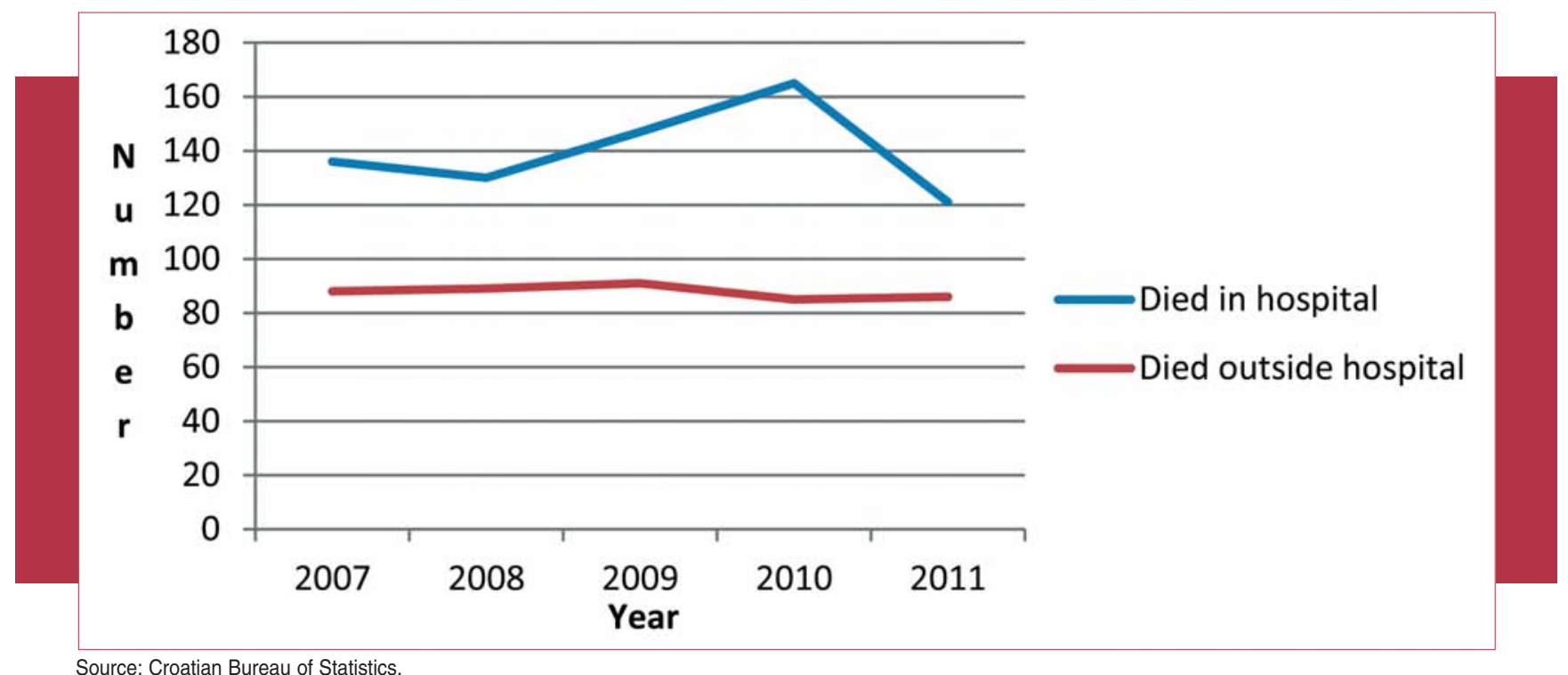

Figure 2. Comparison of in- and out-of-hospital death from acute coronary syndrome among women Zagreb residents (2007-2011).

death. There is no change in out-of-hospital death but the inhospital death shows a declining trend. Each year only about $10 \%$ of the patients included in the ACS Register join the outpatient cardiac rehabilitation program in Zagreb.

Discussion: Advantages of the Register - It is intended for health professionals and policy makers and gives the information on the characteristics, the burden and consequences of ACS in the City of Zagreb. It provides a more precise and valid monitoring of ACS. Continuing hospital computerization and personal identification number should allow record linkage and better data quality. Data is published in the Croatian Health Service Yearbook. Limitations: Financial

Received: $15^{\text {th }}$ Feb 2014

*Address for correspondence: Poliklinika za prevenciju kardiovaskularnih bolesti I rehabilitaciju, Draškovićeva 13, HR-10000 Zagreb, Croatia.

Phone: +385-1-4612-308

Fax: $+385-1-4612-343$

E-mail: inge.heim@srcana.hr problems, lack of data collection staff, unrecognized value of such population-based registers among health professionals, lack of validation of discharge diagnoses. One of the problems is, also, that we no longer have the possibility to check the diagnosis on the death certificate at the Hospital Department of Pathology because the Central Bureau of Statistics refuses to give us the names of deceased patients due to data protection.

Conclusion: Out-of-hospital mortality has declined in the last few decades, but it still remains high representing great concern in men. From the epidemiological point of view emphasis should be placed on CV prevention, population education and better out-of hospital emergency care. The use of a reliable information system has enabled the development of such a register and contributed to a relatively simple data processing. Medical professionals and patients should be better informed on the advantages of the cardiac rehabilitation program.

KEYWORDS: acute coronary syndrome, population-based register, epidemiology, mortality, outpatient cardiac rehabilitation program

CITATION: Cardiol Croat. 2014;9(3-4):100-101.

\section{Literature}

1. Heim I, Jembrek-Gostović M, Kern J, Jonke V, Svetina M. Trends in acute myocardial infarction mortality and morbidity from 1979 to 2001 in the City of Zagreb, Croatia: retrospective study. Croat Med J 2005; 46(6):970-6.

2. Jembrek-Gostović M, Heim I, Hrabak-Žerjavić V, Jonke V. Epidemiološko značenje akutnog koronarnog sindroma u populaciji grada Zagreba. Acta Med Croat. 2004;58:91-3.

3. Heim I, Jonke V, Gostović M, Jembrek-Gostović M. Epidemiologija akutnog koronarnog sindroma u Gradu Zagrebu. Acta Med Croat. 2009;63:105-9.

4. Heim I, Jembrek-Gostović M. Osvrt na bolničku smrtnost s aspekta kliničara i epidemiologa. Cardiol Croat. 2007;2(4):26-7.

5. Heim I, Kruhek Leontić D, Jonke V, Romčević M, Jembrek-Gostović M, Henezi I. Patients in cardiac rehabilitation programme - where we were 1999 and where 10 years later. Coll Antropol. 2012;36(Suppl1):59-63.

6. Heim I, Jembrek-Gostović M. Registar akutnog infarkta miokarda i akutnog koronarnog sindroma za grad Zagreb (akutni infarkt miokarda i nestabilna angina). HČJZ $2011 ; 7$.

7. Heim I, Jembrek-Gostovic M, Jonke V, Gostovic M. Epidemiological data of acute coronary syndrome in Zagreb, the Capital of Croatia in 2000 and 2001 . Eur J Cardiov Prev Rehab. 2004;11(Suppl 1):101.

8. Vervueren PL, Elbaz M, Wagner A, et al. The major element of 1-year prognosis in acute coronary syndromes is severity of initial clinical presentation: results from the French MONICA registries. Arch Cardiovasc Dis. 2012;105(10):478-88. 